\title{
Phytochemical evaluation and antioxidant potential of Praecitrullus fistulosus fruit extracts.
}

\author{
Archana Bollavarapu*, Gangaraju Rapaka and Raghavarao Tamanam. \\ Department of Biochemistry, Andhra University, India.
}

\begin{abstract}
Praecitrullus fistulosus (cucurbitaceae) also called Indian round gourd or tinda is a squash-like cucurbit. The present study was undertaken to evaluate the phytochemicals, enzymatic and non enzymatic antioxidant potential of P. fistulosus fruit extracts. This plant is rich in phytochemicals such as flavanoids, phenols, tannins, cardiac glycosides and terpenoids. All extracts (Hexane, Chloroform, Ethyl acetate, Aqueous) possess high antioxidant and free radical scavenging activities. In vitro antioxidant activities of all crude extracts were significant and comparable with the standard Ascorbic acid and BHT. Activity of the enzymatic antioxidants such as SOD, CAT, GST and MDA were observed to be 25.27U/mg protein, $2359.47 \mathrm{U} / \mathrm{ml}, 2433.46$ $n$ moles of CDNB conjugated/minute and $4878.64 n$ moles $/ g$ tissues at $100 \mathrm{mg} / \mathrm{ml}$ respectively. All extracts possess high antioxidant activity and free radical scavenging activity. In vitro antioxidant activities of all crude extracts were significant and comparable with the standard Ascorbic acid and BHT. Results of the present study suggested that P.fistulosus could be a potential source of natural antioxidant that could have great importance as therapeutic agents in preventing oxidative stress-related degenerative diseases.
\end{abstract}

Keywords: Praecitrullus fistulosus, enzymatic antioxidants, Non-enzymatic antioxidants, Oxidative stress.

\section{Introduction}

There is ample evidence that reactive oxygen species (ROS) generated in the human body can cause oxidative damage associated with many degenerative diseases such as atherosclerosis, coronary heart diseases, aging, and cancer. It is well understood that ROS such as superoxide radical, hydroxyl radical, and nitric oxide radical attack biological molecules such as lipids, proteins, enzymes, DNA, and RNA, leading to cell or tissue injury. There is a rising tendency to use natural drugs and herbal therapies, partly because of the destructive nature and side effects of chemical drugs, as well as environmental pollution [1, 2, 3].

Therefore much attention has been focused on the use of antioxidants, especially natural antioxidants to protect from damage due to free radicals. Sources of natural antioxidants are primarily, secondary metabolites that may occur in all parts of the plants such as fruits, vegetables, nuts, seeds, leaves, roots and bark [4]. Many naturally occurring agents in plant extracts show antimicrobial, antioxidant, antifungal, anticancer and antiinflammatory activities to a greater or lesser extent [5, 6]. Crude extracts of fruits, herbs, vegetables and other plant materials rich in phenolics are increasingly of interest in the food industry, because they retard oxidative degeneration of lipids and there by improve the quality and nutritive value of food [7, 8].

In the series of Cucurbitaceae plants, Praecitrullus fistulosus is one of the excellent plants, gifted by the nature having composition of all the essential constituents that are required for normal and good human health. $P$. fistulosus (cucurbitaceae) also called Indian roundgourd or tinda is a squash-like cucurbit grown for its immature fruit, a vegetable especially popular in South Asia. It is a diffuse annual, creeping or climbing herb with stout stem and rounded fruits of the size of a small turnip, pale or dark green in colour with blackish seeds. P.fistulosus has been used as traditional medicine for curing heart diseases, strokes, controlling blood pressure, cancer etc. The present study was undertaken to report the analysis of phytochemical constituents and to evaluate the antioxidant activity, reducing power and free radical scavenging activity of various extracts of P.fistulosus fruit.

\subsection{Collection of Plant material:}

\section{Materials And Methods}

The fresh fruits of Praecitrullus fistulosus were collected from the local market of Hyderabad. The fruit is a type of berry called a pepo. The fruits are approximately spherical, and $5-8 \mathrm{~cm}$ in diameter. The fruits were washed under running water to remove adhering dirt. The fruit were then sliced and dried for 20 days. The dried fruit were grinded. The powdered samples were then analyzed for various parameters.

\subsection{Preparation of extracts:}

The powdered plant material was extracted with organic solvents like Chloroform, Ethyl acetate and Hexane at their respective boiling points in a soxhlet apparatus. All the solvents were used based upon their increasing polarity index. The solvent was removed under reduced pressure and the dried extract was stored in a 
dessicator till further study. Aqueous extracts were prepared by boiling $1 \mathrm{gm}$ of powder in $25 \mathrm{ml}$ of distilled water at $100^{\circ} \mathrm{C}$.

\subsection{Preliminary phytochemical screening:}

The preliminary phytochemical analysis was used to analyse the presence of compounds namely alkaloids [9],carbohydrates[10], flavonoids[11],cardiac glycosides[12],phenols,tannins [13], saponins[14],steroids[15] and terpenoids [16] as per the standard protocols(Table1).

\subsection{Bioactive Phytochemical determination:}

\subsubsection{Phenols quantification:}

The amounts of total phenolics in extracts were determined according to the Folin- ciocalteu procedure with slight modifications [17].

\subsubsection{Flavonoid quantification:}

Total flavonoid content was measured by the aluminum chloride colorimetric assay [18].

\subsubsection{Tannin quantification:}

The contents of tannins were determined using the Folin-ciocalteu method with slight modifications [19].

\subsection{Determination of Enzymatic and Non enzymatic antioxidant activities:}

Enzymatic and Non enzymatic antioxidant activities were assayed using standard protocols: Superoxide dismutase [20],Catalaseassay[21], GlutathioneS-transferase[22],Malondialdehyde assay[23],DPPH[24],Hydroxyl radical scavenging assay[25],FRAP[26], Reducing power assay[27].

\subsection{Statistical analysis:}

Data were given as mean and standard deviation (SD) obtained from 3 independent experiments and a $\mathrm{p}$ value less than 0.05 was considered as statistically significant.

\subsection{Phytochemical screening:}

\section{Results And Discussion}

Preliminary screening tests are useful in the detection of bioactive compounds and subsequently may lead to drugs discovery and development. In the present study, several phytochemical constituents were evaluated qualitatively and quantitatively. Table 1 shows the results obtained for the phytochemical screening analysis conducted on P.fistulosus fruit extracts. The presence of carbohydrates, cardiac glycosides, steroids and terpenoids were observed in all the 4 extracts analyzed, flavonoids, phenols and tannins were absent in Hexane extract while saponins were present only in Chloroform and Ethyl acetate extract and alkaloids were absent in all the extracts.

Extraction is a fundamental step in the analysis, since it is essential to obtain and purify the desired chemical constituents from the plant material for further characterization. Extraction with different solvents is frequently used for isolation and quantification of antioxidant compounds, and both extraction yield and antioxidant activity of the extracts are strongly correlated with the solvent employed. For this reason, in this work, different solvents were assayed for the extraction of P. fistulosus fruits (Hexane, Chloroform, Ethyl acetate and Aqueous).

Our results support that the edaphic and climatic conditions may promote differences in the synthesis of secondary metabolites which may contribute to the medicinal value as well as physiological activity of the plant part evaluated [28]. Indeed, an Indian study reported that both methanolic and petroleum ether P. fistulosus fruit extracts contained alkaloids [29].

\subsection{Quantitative analysis of phytochemicals:}

Total phenolic content (TPC) has been reported to be directly associated with antioxidant activity. These compounds are known as powerful chain-breaking antioxidants [30, 31].Our results demonstrate that the phenolic contents of various $P$. fistulosus fruit extracts exhibited large variations in TPC levels (Table 2). The highest TPC was observed in Ethyl acetate extract (1126.50 $\pm 0.66 \mathrm{mg}$ GAE/g DW), followed by Chloroform extract (1053.86 $\pm 0.62 \mathrm{mg} \mathrm{GAE} / \mathrm{g} \mathrm{DW})$ and Aqueous extract (472.64 $\pm 0.46 \mathrm{mg} \mathrm{GAE} / \mathrm{g} \mathrm{DW})$ at $100 \mathrm{mg} / \mathrm{ml}$.

Flavonoids are natural phenolic compounds. Many studies have demonstrated a positive correlation between flavonoid amounts and antioxidant activity [32].The results of the colorimetric analysis are given in Table 2. The Chloroform extract contained the highest flavonoid content $(1588.56 \pm 0.68 \mathrm{mg} \mathrm{QE} / \mathrm{g} \mathrm{DW})$ followed by Aqueous and Ethyl acetate extract $(971.66 \pm 0.75,899.24 \pm 0.70 \mathrm{mg} \mathrm{QE} / \mathrm{g} \mathrm{DW})$ at $100 \mathrm{mg} / \mathrm{ml}$ respectively.

Tannins are a class of phenolic compounds consisting of oligomers and polymers of the flavan-3olmonomer units. It has been reported that they possess various biological activities, such as antioxidant activity [33]. The Tannin content of Ethyl acetate extract $(3116.93 \pm 0.51 \mathrm{mg}$ TAE/g DW) was higher than Chloroform and Aqueous extracts $(3075.09 \pm 0.51 \mathrm{mg}$ TAE$/ \mathrm{g} \mathrm{DW}, 1303.40 \pm 0.66 \mathrm{mg}$ TAE$/ \mathrm{g} \mathrm{DW})$ at $100 \mathrm{mg} / \mathrm{ml}$ respectively. 


\subsection{In vitro Antioxidant activities:}

Natural antioxidants are considered to be multifunctional and of high interest as alternatives to synthetic antioxidants to reduce oxidation in complex food systems. It is well known that the antioxidant properties of plant extracts cannot be evaluated by one single method due to the complex nature of phytochemicals. Therefore, at least two methods should be employed in order to evaluate the total antioxidant activity [34]. In this work, various methods SOD,CAT,GST,MDA (Enzymatic) and DPPH, Hydroxyl radical scavenging assay, FRAP and Reducing power assay (non enzymatic) were used to evaluate the antioxidant activities. Statistically significant differences $(\mathrm{p}<0.05)$ were observed.

\subsubsection{Enzymatic antioxidants:}

The levels of antioxidant enzymes assessed in $P$. fistulosus fruit extract are collectively represented in Table 3. All the enzymatic antioxidant activities increased with increasing concentration ranging from 25 to $100 \mathrm{mg} / \mathrm{ml}$. Superoxide dismutase (SOD) is the first antioxidant enzyme to deal with oxy radicals by accelerating the dismutation of superoxide $\left(\mathrm{O}^{2-}\right)$ to hydrogen peroxide $\left(\mathrm{H}_{2} \mathrm{O}_{2}\right)$. Catalase (CAT) is a peroxisomal heme protein that catalyses the removal of hydrogen peroxide formed during the reaction catalysed by SOD. Thus, SOD and CAT acts mutually supportive antioxidative enzymes which provide protective defense against reactive oxygen species[35]. In the present study, the superoxide dismutase (SOD) activity of $P$. fistulosus fruit extract at $100 \mathrm{mg} / \mathrm{ml}$ was found to be $25.27 \pm 0.42 \mathrm{U} / \mathrm{mg}$ protein whereas the catalase (CAT) activity was observed to possess $2359.47 \pm 0.44 \mathrm{U} / \mathrm{ml}$.

Glutathione S-transferases(GST) are multifunctional proteins involved in diverse intracellular events such as primary and secondary metabolisms, stress metabolism, herbicide detoxification and plant protection against ozone damages, heavy metals and xenobiotics [36].GST activity at $100 \mathrm{mg} / \mathrm{ml}$ was found to be $2433.46 \pm$ $0.47 \mathrm{n}$ moles of CDNB conjugated/minute. In our study the Malonialdehyde (MDA) level was found to be $4878.64 \pm 0.37 \mathrm{n}$ moles/g tissue in fresh sample of $P$. fistulosus.

\subsubsection{Non Enzymatic antioxidants:}

Diphenyl Picryl hydrazyl (DPPH) assay is an effective method to measure the scavenging power. The principle of the DPPH is based on the color changes from purple (DPPH solution) to yellow [24].The color changes can be measured quantitatively at the absorbance $517 \mathrm{~nm}$. The reduction capability of DPPH radical was determined by the decrease in absorbance induced by plant antioxidants. The measured DPPH activity of various extracts in dose dependent manner at $100 \mu \mathrm{g} / \mathrm{ml}$ was $72.62 \pm 0.34 \%$ (Hexane), $65.69 \pm 0.55 \%$ (Chloroform), $58.89 \pm 0.46 \%$ (Ethyl acetate) and $56.9 \pm 0.48 \%$ (Aqueous) $\%$ of inhibition per $50 \mu \mathrm{l}$ of extract as compared to $91.79 \pm 0.49$ and $89.54 \pm 0.54 \%$ of inhibition per $1 \mathrm{mg} / \mathrm{ml}$ of Ascorbic acid and BHT as positive controls. The scavenging effect of various extracts and standard were in the following order: ascorbic acid $>$ BHT $>$ Hexane extract $>$ Chloroform extract $>$ Ethyl acetate extract $>$ Aqueous extract (Fig 1).

In biological system, the hydroxyl radical is the most extremely reactive oxygen centered radicals and it has been implicated as a highly damaging species in free radical pathology, and also highly responsible for producing deleterious effects in the living cells which in turn cause severe damage to the lipids and proteins . Since phenolic compounds are good electron donors, they may accelerate the conversion of $\mathrm{H}_{2} \mathrm{O}_{2}$ into $\mathrm{H}_{2} \mathrm{O}$. The samples exhibited hydroxyl radical scavenging activity in dose dependent manner in the range of $25-100 \mu \mathrm{g} / \mathrm{ml}$. In general the Hydroxyl radical scavenging activity observed in the present study was in the order: Aqueous extract $>$ Chloroform extract $>$ Hexane extract $>$ Ethyl acetate extract. Observed Hydroxyl radical scavenging of various extracts at $100 \mu \mathrm{g} / \mathrm{ml}$ was $59.37 \pm 0.50 \%$ (Ethyl acetate), $57.19 \pm 0.55 \%$ (Chloroform), $42.68 \pm 0.67 \%$ (Hexane)and $38.39 \pm 0.37 \%$ (Aqueous) $\%$ of inhibition per $0.1 \mathrm{ml}$ of extract as compared to $81.58 \pm 0.60 \%$ and $67.00 \pm 0.56 \%$ of inhibition per $1 \mathrm{mg} / \mathrm{ml}$ of Ascorbic acid and BHT as positive controls (Fig 2).

Ferric Reducing Antioxidant Power (FRAP) is a simple inexpensive assay and may offer index of antioxidant activity. Frap assay measures the reducing potential of an antioxidant reacting with a ferric tripyridyltriazine $\left[\mathrm{Fe}^{3+}-\mathrm{TPTZ}\right]$ complex and producing a coloured ferrous tripyridyltriazine $\left[\mathrm{Fe}^{2+}-\mathrm{TPTZ}\right]$ [26].Generally, the reducing properties are associated with the presence of compounds which exert their action by breaking the free radical chain by donating a hydrogen atom. FRAP assay treats the antioxidants in the sample as a reductant in a redox-linked colorimetric reaction. Ferric ion reducing activities of P.fisulosus were shown in Fig 3. The absorbance of P.fisulosus clearly increased, due to the formation of the $\mathrm{Fe}^{2+}-\mathrm{TPTZ}$ complex with increasing concentration. Ferric reducing ability was found to be maximum in Chloroform extract (7856.67 \pm 0.48$)$, followed by Aqueous extract (4366.54 \pm 0.61$)$, with Ethyl acetate extract $(3833.55 \pm 0.39)$ and very low in Hexane extract $(978.55 \pm 0.39)$.

$\mathrm{Fe}$ (III) reduction is often used as an indicator of electron donating activity, which is an important mechanism of phenolic antioxidant action. In the reducing power assay, the presence of antioxidants in the samples would result in the reducing of $\mathrm{Fe}^{3+}$ to $\mathrm{Fe}^{2+}$ by donating an electron. Amount of $\mathrm{Fe}^{2+}$ complex can be then monitored by measuring the formation of Perl's Prussian blue at $700 \mathrm{~nm}$ [27]. Increasing absorbance at 700 
$\mathrm{nm}$ indicates an increase in reductive ability. In Fig 4 the results of the reducing power assay were displayed. It was found that the reducing powers of all the extracts increased with increase in their concentrations. A higher absorbance indicates a higher ferric reducing power. The reducing power assay was found to be high in Chloroform extract (2792.33 \pm 0.57$)$, followed by Aqueous extract (1911.05 \pm 0.47$)$, Ethyl acetate extract $(1067.55 \pm 0.47)$ and very low in Hexane extract (123.18 \pm 0.44$)$.

The results of the present study indicate that all extracts possess high antioxidant activity and free radical scavenging activity. Due to good quality flavonoid, tannin and phenolic content, Chloroform extract have been found to possess comparatively potent antioxidant activity than other extracts. Surprisingly, hexane extract which did not reveal the presence of phenolics also exhibited good free radical scavenging activity, suggesting that Hexane extracts contain some non phenolic constituents which are responsible for its antioxidant activity.

\section{Figures And Table}

Table1: Phytochemical screening of Praecitrullus fistulosus.

\begin{tabular}{|c|c|c|c|c|}
\hline $\begin{array}{c}\text { PHYTOCHEMICAL } \\
\text { CONSTITUENTS }\end{array}$ & $\begin{array}{c}\text { HEXANE } \\
\text { EXTRACT }\end{array}$ & $\begin{array}{c}\text { CHLOROFORM } \\
\text { EXTRACT }\end{array}$ & $\begin{array}{c}\text { ETHYLACETATE } \\
\text { EXTRACT }\end{array}$ & $\begin{array}{c}\text { AQUEOUS } \\
\text { EXTRACT }\end{array}$ \\
\hline Alkaloids & - & - & - & - \\
\hline Carbohydrate & + & + & + & + \\
\hline Cardiac glycosides & + & + & + & + \\
\hline Flavonoids & - & + & + & + \\
\hline Phenols & - & + & + & + \\
\hline Steroids & + & + & + & - \\
\hline Saponins & - & + & + & + \\
\hline Tannins & - & + & + & + \\
\hline Terpenoids & + & + & + & + \\
\hline
\end{tabular}

"+" indicates presence of phytochemicals; " "-" indicates absence of phytochemicals

Table 2: Quantitative analysis of phytochemicals in various extracts of P.fistulosus fruit.

\begin{tabular}{|c|c|c|c|c|}
\hline \multirow{2}{*}{$\begin{array}{c}\text { Phytochemical } \\
\text { constituents }\end{array}$} & \multicolumn{3}{|c|}{ Praecitrullus fistulosus fruit extracts } \\
\cline { 2 - 5 } & Hexane & Chloroform & Ethylacetate & Aqueous \\
\hline $\begin{array}{c}\text { Phenolics*(mg } \\
\text { GAE/gDW) }\end{array}$ & - & $\mathbf{1 0 5 3 . 8 6} \pm \mathbf{0 . 6 2}$ & $\mathbf{1 1 2 6 . 5 0 \pm 0 . 6 6}$ & $\mathbf{4 7 2 . 6 4 \pm 0 . 4 6}$ \\
\hline $\begin{array}{c}\text { Flavonoids*(mg } \\
\text { QE/gDW) }\end{array}$ & - & $\mathbf{1 5 8 8 . 5 6} \pm \mathbf{0 . 6 8}$ & $\mathbf{8 9 9 . 2 4 \pm 0 . 7 0}$ & $\mathbf{9 7 1 . 6 6 \pm 0 . 7 5}$ \\
\hline $\begin{array}{c}\text { Tannins*(mg } \\
\text { TAE/gDW) }\end{array}$ & - & $\mathbf{3 0 7 5 . 0 9} \pm \mathbf{0 . 5 1}$ & $\mathbf{3 1 1 6 . 9 3} \pm \mathbf{0 . 5 1}$ & $\mathbf{1 3 0 3 . 4 0 \pm 0 . 6 6}$ \\
\hline
\end{tabular}

GAE-gallic acid equivalence; QE- quercetin equivalence; TAE-tannic acid equivalence ; gDW-gram dry weight *Values expressed as mean \pm standard deviation obtained from 3 measurements.

Table 3: Levels of enzymatic antioxidants present in fresh sample of P. fistulosus.

\begin{tabular}{|c|c|c|}
\hline S.NO & Parameters & Values \\
\hline 1. & Superoxide Dismutase & $25.27 \pm 0.42$ \\
\hline 2. & Catalase & $2359.47 \pm 0.44$ \\
\hline 3. & Glutathione S transferase & $2433.46 \pm 0.47$ \\
\hline 4. & Malondialdehyde & $4878.64 \pm 0.37$ \\
\hline
\end{tabular}

Units: SOD: Units/mg protein, CAT: unit/ml, GST: n moles of CDNB conjugated/minute. MDA: n moles/g tissue .Values are expressed as Mean $\pm \operatorname{SD}(n=3)$.

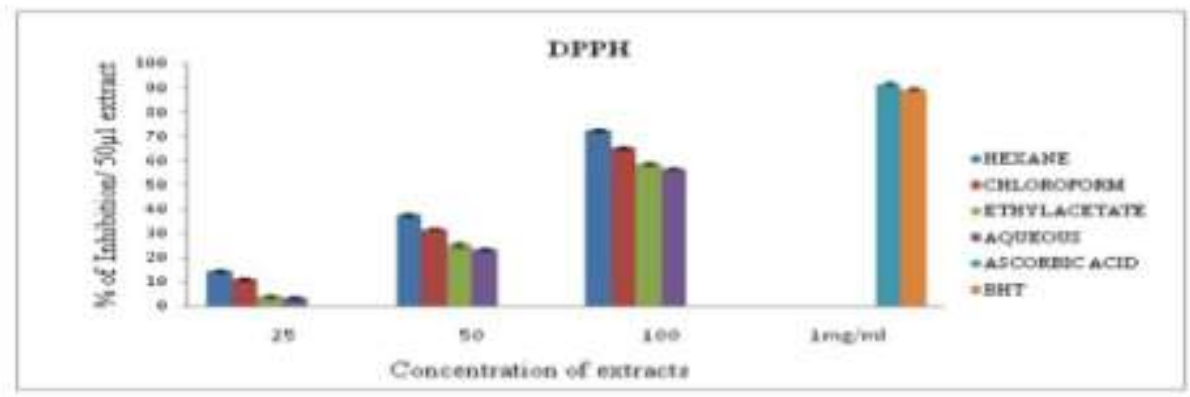

Fig1: DPPH activity of various extracts of P. fistulosus fruit. 


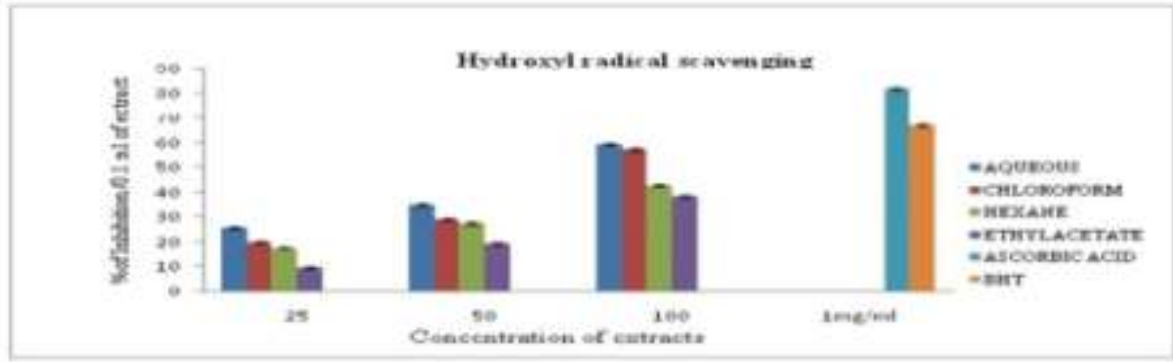

Fig 2 : Hydroxyl radical scavenging activity of various extracts of $P$. fistulosus fruit.

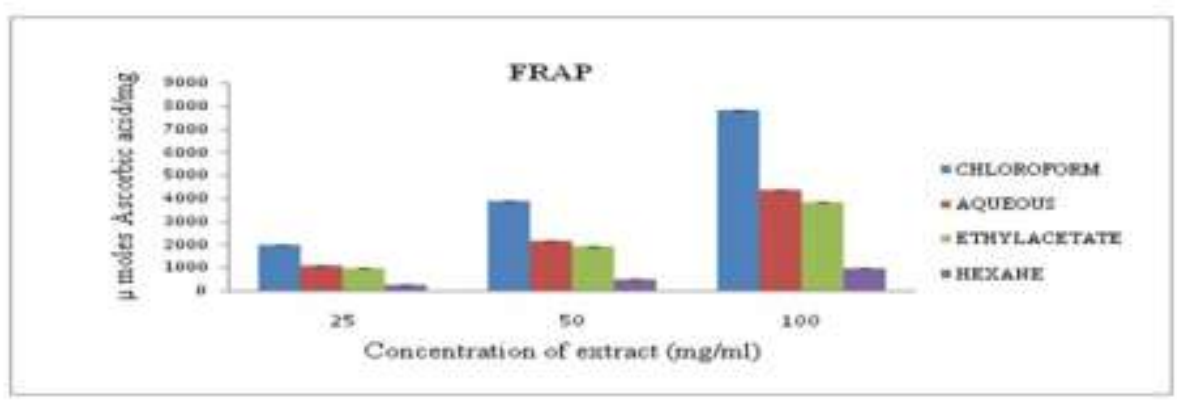

Fig 3: FRAP activity of various extracts of $P$. fistulosus fruit.

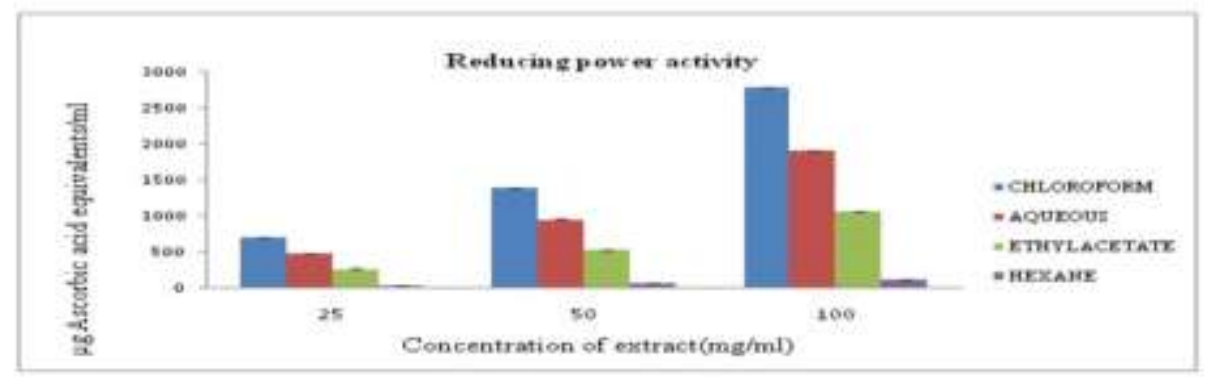

Fig4: Reducing power activity of various extracts of $P$. fistulosus fruit.

\section{Conclusion}

Searching plant sources may bring new natural products into pharmaceutical, cosmetic and food production. Interest in the role of antioxidants in human health has prompted research in the fields of food science and horticulture to assess fruit and vegetable antioxidants. It can be concluded that the P.fistulosus possesses the significant antioxidant activity and could serve as free radical inhibitors or scavengers, acting possibly as primary antioxidants, which might be due to its flavonoid, phenolic and other phytochemical constituents. The findings of the present study suggested that P.fistulosus could be a potential source of natural antioxidant that could have great importance as therapeutic agents in preventing or slowing the progress of aging and age-associated oxidative stress-related degenerative diseases. Hence, it is worthwhile to isolate and elucidate the bioactive principle that one responsible for the antioxidant activity.

\section{Acknowledgements}

This research did not receive any specific grant from funding agencies in the public, commercial, or not-forprofit sector.

\section{References}

[1]. Balunas MJ, Kinghorn AD (2005) Drug discovery from medicinal plants. Life Sci 78(5):431-441. doi:10.1016/j.lfs.2005.09.012.

[2]. Rad JS, Alfatemi SH, Rad MS, Iriti M (2013a) In-vitro antioxidant and antibacterial activities of Xanthium strumarium L. extracts on methicillin-susceptible and methicillin-resistant Staphylococcusaureus. Ancient Sci Life 33:109-113. doi:10.4103/02577941.139050

[3]. Sharifi-Rad J, Hoseini-Alfatemi SM, Sharifi-Rad M, Setzer WN(2014) Chemical composition, antifungal and antibacterial activities of essential oil from Lallemantia royleana (Benth. inWall.) Benth. J Food Safety. doi:10.1111/jfs.12139.

[4]. Pratt, D.E., Hudson, B.J.F., 1990. Natural antioxidants not exploitedcommercially. In: Hudson, B.J.F. (Ed.), Food Antioxidants.Elsevier, Amsterdam, pp. 171-192.

[5]. Patwardhan B (2005) Ethnopharmacology and drug discovery. J Ethnopharmacol100(1-2):50-52. doi:10.1016/j.jep.2005.06.006. 
[6]. Rad JS, Alfatemi SMH, Rad MS (2014a) In vitro assessment ofantibacterial activity of Salicornia herbacea L. seed extracts against multidrug resistant gram-positive and gram-negativebacteria. Int. J Biosci 4(6):217-222. doi:10.12692/ijb/4.6.217-222.

[7]. Ka“hko“nen, M.P., Hopia, A.I., Vuorela, H.J., Rauha, J.P., Pihlaja, K.,Kujala, T.S., Heinonen, M., 1999. Antioxidant activity of plant extracts containing phenolic compounds. Journal of Agricultural and Food Chemistry 47, 3954-3962.

[8]. Rice Evans, C., Miller, N.J., Bolwell, G.P., Bramley, P.M., Pridham,J.B., 1995. The relative antioxidant activities of plant derived polyphenolic flavonoids. Free Radical Research 22, 375-383.

[9]. R.Roopashree, S.Dang, and N.C.Rani, (2008). Antibacterial activity of antipsoriatic herbs: Cassia tora, Momordica charantia and Calendula officinalis. International Journal of Applied Research in Natural Products: Vol.1 (3) 20-28.

[10]. D.Abba, H.I.Inabo, S.E.Yakubu, and O.S.Olonitola (2009). Phytochemical analysis and antibacterial activity of some powdered herbal preparations marketed in Kaduna metropolis. Science World Journal: Vol.4 (1) 23-26.

[11]. R.N.S.Yadav and M.Agarwala (2011). Phytochemical analysis of some medicinal plants. Journal of Phytology: Vol.3 (12) $10-14$.

[12]. O.V.Njoku and C.Obi (2009). Phytochemical constituents of some selected medicinal plants. African Journal of Pure and Applied Chemistry: Vol.3 (11) 228-233.

[13]. 13. Sharma etal; Antimicrobial and Phytochemical Evaluation of Jatropha curcas. Linn, Pharmacognosy Journal: Vol4 Issue 30

[14]. Evans WC. Trease and Evans Pharmacognosy, 14th Edition, Bailiere Tindall W.B. Sauders company ltd; London, 1996, 224 - 228, $293-309,542-575$.

[15]. Harborne JB., Methods of plant analysis. In: Phytochemical Methods (Chapman and Hall, London. 1973).

[16]. H.O.Edeoga, D.E.Okwu and B.O.Mbaebie (2005). Phytochemical constituents of some Nigerian medicinal plants. African Journal of Biotechnology: Vol.4 (7) 685-688.

[17]. Javanmardi J, Stushnoff C, Locke E, Vivanco JM (2003) Antioxidant activity and total phenolic content of Iranian Ocimum accessions. Food Chemistry 83: 547-550.

[18]. Zhishen J, Mengcheng T, Jianming W. The determination of flavonoid contents in mulberry and their scavenging effects on superoxide radicals. Food Chem 1999; 64: 555-9.

[19]. Folin O, Ciocalteu V (1927) On tyrosine and tryptophane determinations in proteins. Journal of Biological Chemistry 73: 627-650.

[20]. Beuchamp and Fedovich B. C. (1976). "Superoxide Dismutase assay and an Assay Applicable to Acrylamide Gel". Anal Biochem. 10: $276-287$.

[21]. Cohen D, Dembiec D, Marcus J. Measurement of catalase activity in tissue extracts. Annals Biochem. 1970; 34, 30-38.

[22]. Habig WH, Pabst MJ and Jacoby WB,Glutathione-S-transferase: the firstenzymatic step in mercapturic acid fermentation,J. Biol. Chem, 249:7310-7339. (1974).

[23]. Buege JA, Aust SD. Microsomal lipid, Peroxidation. In: Flesicher, S., Packer, L. (Eds.), Methods in Enzymology Vol. 52. (Academic Press, New-York, 1978) pp. 302-310.

[24]. Gyamfi MA, Yonamine M, Aniya Y. Free-radical scavenging action of medicinal herbs from Ghana: Thonningia sanguinea on experimentally induced liver injuries. Gen Pharmacol. 1999;32:661-7.

[25]. Gulhan VU, Ferda C, Atalay S, Dimitra D, Moschos P, et al. (2003) Antimicrobial and Antioxidant Activity of the Essential Oil and Methanol Extracts of Thymus pectinatus Fisch. et Mey. Var. pectinatus (Lamiaceae). J Agric Food Chem 51: 63-67.

[26]. Benzie IFF, Strain JJ (1996) The Ferric reducing ability of plasma (FRAP) as a measure of antioxidant power: The FRAP assay. Analytical Biochemistry 239: 70-76.

[27]. Oyaizu M. Jap J Nutr 1986; 44:307-315.

[28]. Edoga, H.O., Okwu, D.E., Mbaebie, B.O., 2005. Phytochemicals constituents of some Nigerian medicinal plants. Afr. J. Biotechnol. 4, 685-688.

[29]. Gautam S and Shivhare Y. Phytochemical Screening and Antioxidant Potential of Praecitrullus fistulosus. Journal of Advanced Pharmacy Education \& Research, 1(5), 2011, 238-242.

[30]. Ksouri R, Megdiche W, Falleh H, Trabelsi N, Boulaaba M, Smaoui A, et al. Influence of biological, environmental and technical factors on phenolic content and antioxidant activities of Tunisian halophytes. C R Biol 2008;331:865e73

[31]. Maisuthisakul P, Suttajit M, Pongsawatmanit R. Assessment of phenolic content and free radical-scavenging capacity of some Thai indigenous plants. Food Chem 2007;100:1409e18.

[32]. Cakir A, Mavi A, Yıldırım A, Duru ME, Harmandar M, Kazaz C. Isolation and characterization of antioxidant phenolic compounds from the aerial parts of Hypericum hyssopifolium L by activity-guided fractionation. J Ethnopharmacol 2003;87:73e83.

[33]. Vinson JA, Dabbagh YA, Serry MM, Jang J. Plant flavonoids, especially tea flavonols are powerful antioxidants using an in vitro oxidation model for heart disease. J Agri Food Chem 1995; 43:2800e2.

[34]. Ilhami Gulcin, Haci Ahmet Alici, Mehmet Cesur. Determination of in vitro antioxidant and radical scavenging activities of propofol. Chem Pharm Bull. 2005; 53: 281 - 285.

[35]. AyyakkannuPurushothaman,ElumalaiNandhakumar,PanchanathamSachdanandam.Modulation of lipid peroxidation and antioxidant status upon administration of "Shemamruthaa" in 7,12-dimethylbenz(a)anthracene induced mammary carcino bearing rats. Asian Pacific Journal of Tropical Biomedicine 2012:S765-S771.

[36]. Sasan Mohsenzadehi, Maryam Esmaeilil, Fateme Moosavil,Maryam Shahrtash,Babak. Plant glutathione stransferase classification, structure and evolution. African Journal of Biotechnology 2011:10(42):8160-8165. 